\title{
Snow-sourced bromine and its implications for polar tropospheric ozone
}

\author{
X. Yang ${ }^{1,2}$, J. A. Pyle ${ }^{1,2}$, R. A. Cox ${ }^{1}$, N. Theys ${ }^{3}$, and M. Van Roozendael ${ }^{3}$ \\ ${ }^{1}$ National Centre for Atmospheric Science (NCAS), Cambridge, CB2 1EW, UK \\ ${ }^{2}$ Centre for Atmospheric Science, Department of Chemistry, University of Cambridge, Cambridge CB2 1EW, UK \\ ${ }^{3}$ Institut d'Aéronomie Spatiale de Belgique (IASB-BIRA), Brussels, Belgium
}

Received: 24 February 2010 - Published in Atmos. Chem. Phys. Discuss.: 29 March 2010

Revised: 16 July 2010 - Accepted: 27 July 2010 - Published: 24 August 2010

\begin{abstract}
In the last two decades, significant depletion of boundary layer ozone (ozone depletion events, ODEs) has been observed in both Arctic and Antarctic spring. ODEs are attributed to catalytic destruction by bromine radicals ( $\mathrm{Br}$ plus $\mathrm{BrO}$ ), especially during bromine explosion events (BEs), when high concentrations of $\mathrm{BrO}$ periodically occur. However, neither the exact source of bromine nor the mechanism for sustaining the observed high $\mathrm{BrO}$ concentrations is completely understood. Here, by considering the production of sea salt aerosol from snow lying on sea ice during blowing snow events and the subsequent release of bromine, we successfully simulate the BEs using a global chemistry transport model. We find that heterogeneous reactions play an important role in sustaining a high fraction of the total inorganic bromine as $\mathrm{BrO}$. We also find that emissions of bromine associated with blowing snow contribute significantly to $\mathrm{BrO}$ at mid-latitudes. Modeled tropospheric $\mathrm{BrO}$ columns generally compare well with the tropospheric $\mathrm{BrO}$ columns retrieved from the GOME satellite instrument (Global Ozone Monitoring Experiment). The additional blowing snow bromine source, identified here, reduces modeled high latitude lower tropospheric ozone amounts by up to an average $8 \%$ in polar spring.
\end{abstract}

\section{Introduction}

Bromine radicals ( $\mathrm{Br}$ plus $\mathrm{BrO}$ ) are important atmospheric halogen species which may regulate ozone concentrations in both the stratosphere and troposphere (World Meteorological Organization (WMO), 2003; von Glasow et al., 2004; Salawitch et al., 2005; Yang et al., 2005) and which also have significant effects on other tropospheric processes such

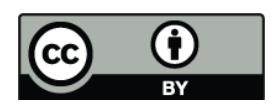

Correspondence to: $\mathrm{X}$. Yang (xin.yang@atm.ch.cam.ac.uk) as the sulfur cycle (von Glasow and Crutzen, 2004; Breider et al., 2009) and mercury oxidation (Holmes et al., 2006; Seigneur and Lohman, 2008). Significant ozone depletion events (ODES), first observed in the boundary layer in polar spring (Barrie et al., 1998; Wessel et al., 1998), are attributed to catalytic destruction by halogen radicals, especially during bromine explosion events (BEs, see, e.g., McConnell et al., 1992; Fan and Jacob, 1992). However, the mechanism for the bromine release during BEs is not completely clear. Photochemical reactions within the snow pack could result in bromine release (Foster et al., 2001; Simpson et al., 2005, 2007). Frost flowers have also been suggested as a potentially important bromine source (Kaleschke et al., 2004; Sander et al., 2006), but are not likely to be a direct source, although when frost flowers are dispersed into the atmosphere by strong surface winds they could make some contribution (Alvarez-Aviles et al., 2008). A recent calculation demonstrates that the sea salt produced in association with blowing snow events could be a significant bromine source (Yang et al., 2008), which is consistent with recent insitu measurements of higher bromide levels in blowing snow in coastal Antarctica (Jones et al., 2009). Inclusion of this source in the Arctic has a significant effect on tropospheric $\mathrm{BrO}$ and oxidation (through ozone and $\mathrm{OH}$ ) (Voulgarakis et al., 2009).

Snow lying on sea ice accumulates sea salt through various pathways. Using measurements of the mean column salinity of snow on young Antarctic sea ice (Massom et al., 2001) and a parameterization for sea salt aerosol production in blowing snow events, we have found that the resulting sea salt aerosol production rate (per unit area under typical weather conditions) can be more than an order of magnitude larger than that from the open ocean (Yang et al., 2008). This finding is consistent with observations of sea salt aerosol magnitude and seasonality (Hall et al., 1998) and also with the ice-core records (Rankin et al., 2002). Here, by considering the sea salt production from snow lying on sea ice during blowing

Published by Copernicus Publications on behalf of the European Geosciences Union. 
snow events and the subsequent bromine release, we aim to simulate the BEs. The scheme is evaluated by direct comparisons with tropospheric $\mathrm{BrO}$ columns retrieved from the GOME satellite instrument.

In Sect. 2, we present details of the model scheme for the bromine release and the additional heterogeneous bromine chemistry as implemented in a global chemical transport model, p-TOMCAT. Sect. 3 describes the retrieval of tropospheric $\mathrm{BrO}$ columns from the GOME satellite instrument. Sect. 4 compares the model and observations. In Sect. 5, the sensitivity of the model to both snow salinity and the sea salt bromine depletion factor is explored. Finally, conclusions are reached in Sect. 6.

\section{Model tropospheric $\mathrm{BrO}$}

\subsection{Basic model information}

p-TOMCAT is a chemistry-transport model which has been widely used for tropospheric chemistry studies. Here it is forced by ECMWF reanalysis data and run at a horizontal resolution of approximately $5.6^{\circ}$ with 31 vertical layers up to $10 \mathrm{hpa}$. Runs are based on an earlier model version, which includes bromine chemistry in the troposphere (Yang et al., 2005). In this study, we include the bromine source from polar sea ice, as introduced by Yang et al. (2008), in addition to the two sources already included in our previous studies: open ocean sea salt (Yang et al., 2005) and bromocarbons (Warwick et al., 2006). For more detailed information about the physical and chemical aspects of the model, see related papers by Wang et al. (1999), Savage et al. (2004), O'Connor et al. (2005), Cook et al. (2007) and O'Brien et al. (2009).

\subsection{Main features of the blowing snow scheme}

Snow, lying on sea ice, contains bromine salts. The new bromine source included in these calculations arises when wind lifts this bromine-containing snow into the atmosphere. Many of the underlying processes are not included in the base CTM and have to be either specified or parameterized. Their treatment, described in detail in Yang et al. (2008), is outlined here in Sects. 2.3 to 2.5.

The scheme requires the spatial and temporal coverage of sea ice. We do not attempt to model this; instead, here we use two sea ice data sets: monthly global sea ice (Comiso, 1990, updated 2005) and multiyear sea ice in the Arctic (Kwok, 2004). The essential features of the subsequent calculation of the bromine flux from above the sea ice are given in Sect. 2.3. The calculation depends on the rate at which snow particles are lifted from the surface and subsequent sublimation (which depends on wind speed, temperature, environmental relative humidity and the age of snow) and the rate of release of bromine from the suspended sea salt aerosol (which is obtained from observed bromine depletion factors, salinity, etc.). Snow salinity is discussed in more detail in Sect. 2.4.
An important new feature of the model is the inclusion of additional heterogeneous reactions, which reactivate bromine compounds. These are presented in Sect. 2.5.

\subsection{Bromine emission from blowing snow}

As described in Yang et al. (2008), for a mean snow particle salinity $\varsigma$ in psu, the bromine release flux (in units of $\mathrm{kg} \mathrm{Br} / \mathrm{m}^{2} \mathrm{~s}$ ) summed over the wet particle diameters, $\mathrm{d}_{\mathrm{i}}$, from blowing snow sea salt aerosols can be expressed as:

$Q_{\mathrm{Br}}=R_{\mathrm{a}} \sum_{i} \frac{\mathrm{DF}\left(d_{\mathrm{dry}}\right) f\left(d_{i}\right) Q_{\mathrm{s}} \varsigma}{1000}$ only for $d_{\mathrm{dry}}<10 \mu \mathrm{m}$

where $Q_{\mathrm{s}}$ is the blowing snow sublimation rate (in units of $\mathrm{kg} / \mathrm{m}^{2} \mathrm{~s}$ ) and follows the approach of Dery and Yau (1999, 2001, 2002). $Q_{\text {s }}$ is a complex function of wind speed at $10 \mathrm{~m}$, air temperature, environmental relative humidity and snow age (see Eq. (1) of Yang et al., 2008). DF are sizedependent bromine depletion factors based on observations collected by Sander et al. (2003). $R_{\mathrm{a}}=0.00233 \mathrm{~kg} / \mathrm{kg}$ is the $\mathrm{Br} / \mathrm{NaCl}$ mass ratio in sea salt. $f\left(d_{i}\right)$ is the suspended particle probability density in blowing events which follows a two-parameter gamma probability function (Schmidt, 1982). The snow age also affects $Q_{\text {s. }}$. In Yang et al. (2008) the sensitivity of the calculation to two different specified ages ( 3 and 7 days) was considered. Results were not very sensitive to this change. In this calculation, for each grid box containing sea ice, the snow age is given by the time since precipitation last fell at that location.

Generally, a large sublimation flux is expected under conditions of low relative humidity and high wind speed and in consequence this leads to high sea salt production and bromine release. However, as mentioned by Yang et al. (2008), only fine sea salt with dry diameter $d_{\text {dry }}<10 \mu \mathrm{m}$ is treated as a bromine source. Snow salinity has two effects on the bromine release. First, increased salinity leads directly to an increased bromine source ( $Q_{\mathrm{Br}}$ varies linearly with $\varsigma$ in Eq. (1)). However, salinity also affects the aerosol size distribution. For example, reducing the snow salinity leads to more sea salt aerosol of small diameter $(<10 \mu \mathrm{m})$, which then offsets the direct effect of lower salinity on the total bromine release. So, the response of bromine release to changing salinity is non-linear.

A further factor affecting bromine release is the depletion factor; $Q_{\mathrm{Br}}$ varies linearly with $\mathrm{DF}$ (see Eq. (1)). DF values used in this study are taken from Yang et al. (2008), in which DF is specified as a function of particle size, based on the dataset compiled by Sander et al. (2003), in order to estimate bromine release from differently sized sea salt aerosol particles. Certainly, bromine depletion in sea salt is related to conditions in the marine environment and the spatial and temporal variations in DF are controlled by the balance between available acidity (uptake of $\mathrm{SO}_{2}, \mathrm{HNO}_{3}$, $\mathrm{RCOOH}$, etc.) and sea salt. Thus, using a fixed DF globally is an important contribution to the overall model 
uncertainty. Breider et al. (2009) also used the Sander et al. (2003) dataset in their modeling study. They took median values, which can be more than a factor of 2 higher than the mean values that we have used. We will explore the sensitivity of the model to DF in Sect. 5.

\subsection{Snow salinity}

Many factors influence the supply of ionic salt to snow deposited on the sea ice including frost flowers on young sea ice, upwards migration of brine within snow, input of sea salt aerosols from adjacent leads or polynyas and flooding, etc. Strong surface winds in polar regions will redistribute these salty particles. The snow salinity used in the model is based on the detailed analysis of data reviewed by Massom et al. (2001) for Antarctic first year sea ice. However, to our knowledge, although there are isolated measurements in the Arctic, we have not seen a similar collection of snow salinity data for the Arctic. Of course, scaling-up local or regional observations to the global scale is always a significant challenge. To extrapolate Antarctic snow salinity to the Arctic is not straightforward; there are significant differences in both oceanic and atmospheric environments. For example, firstly, according to precipitation data (Huffman et al., 2001), winter precipitation in the Antarctic (April to September at $\left.60-70^{\circ} \mathrm{S}\right)$ is about 3.5 times that of the Arctic $\left(>70^{\circ} \mathrm{N}\right.$ from October to March), implying that the snow salinity in the Arctic is less diluted. Secondly, the Arctic ocean has large areas of multiyear sea ice. The snow salinity will be reduced there, as a lower flooding frequency is expected over the multiyear sea ice compared to first year ice. In this study, we linearly extrapolate the Antarctic snow salinity from Massom et al. (2001) to Arctic first year sea ice. Assuming that there is a similar saline supply to sea ice snow in both polar regions and taking the N-S snowfall differences discussed above, the Arctic snow salinity on young sea ice will be about 3.5 times that of the Antarctic. Furthermore, we assume that there is no sea salt aerosol production from multiyear sea ice; only new ice is considered. Clearly, the extrapolation of observed Antarctic salinity to the Arctic is an important assumption whose impact on modeled bromine we explore in Sect. 5 .

\subsection{Treatment of reactivation of inactive bromine species}

Three heterogeneous reactions on aerosols are introduced in a novel parameterization to reactivate $\mathrm{Br}$ radicals from the $\mathrm{HBr}$ reservoir, which is formed in the standard gas phase bromine photochemistry.

$$
\begin{aligned}
& \mathrm{HBr}+\mathrm{HOBr} \stackrel{\text { het }}{\longrightarrow} \mathrm{Br}_{2}+\mathrm{H}_{2} \mathrm{O} \\
& \mathrm{HBr}+\mathrm{BrONO}_{2} \stackrel{\text { het }}{\longrightarrow} \mathrm{Br}_{2}+\mathrm{HNO}_{3} \\
& \mathrm{HBr}+\mathrm{N}_{2} \mathrm{O}_{5} \stackrel{\text { het }}{\longrightarrow} \mathrm{BrNO}_{2}+\mathrm{HNO}_{3}
\end{aligned}
$$

In the clean troposphere, most of the aerosol, except for fresh sea salt, contains very low $\mathrm{Br}^{-}$and the rate of Reactions (R1)-(R3) depends on the supply of each reactant from the gas phase and their relative abundance on the aerosol surface. We use Reaction (R1) as an example to show how we derive effective heterogeneous reaction rates in the model. We simply assume there is no net bromine accumulation in the aerosol and that the reaction occurs instantaneously on the surface. Then, Reaction (R1) can be rewritten into two individual heterogeneous half-reactions by introducing a hypothetical transient reservoir species BrY, which has the same properties as $\mathrm{Br}_{2}$, but only contains one bromine atom.

$$
\begin{aligned}
& \mathrm{HOBr}+\text { aerosol } \rightarrow \mathrm{BrY}+\mathrm{H}_{2} \mathrm{O} \\
& \mathrm{HBr}+\text { aerosol } \rightarrow \mathrm{BrY}
\end{aligned}
$$

Their rates in general would be given by

$\mathrm{R}_{4}=\gamma_{0(\mathrm{HOBr})} v_{(\mathrm{HOBr})} A[\mathrm{HOBr}] / 4$

$\mathrm{R}_{5}=\gamma_{0(\mathrm{HBr})} v_{(\mathrm{HBr})} A[\mathrm{HBr}] / 4$

where $\gamma_{0(\mathrm{HOBr})}$ and $\gamma_{0(\mathrm{HBr})}$ are the maximum uptake coefficients measured (when the surface is completely saturated with the second reactant); $v_{(\mathrm{HOBr})}$ and $v_{(\mathrm{HBr})}$ are molecular speeds; and $[\mathrm{HOBr}]$ and $[\mathrm{HBr}]$ are concentrations of reactant $\mathrm{HOBr}$ and $\mathrm{HBr} . A\left(\mathrm{~cm}^{2} / \mathrm{cm}^{3}\right)$ is the aerosol surface area density.

Obviously, the rate of the overall reaction is limited by the slower of these two rates so that, in the model, both halfreaction rates are set to the slower of the two rates.

The uptake coefficients used in this study are estimated to be $\gamma_{0(\mathrm{HBr})}=0.2, \gamma_{0(\mathrm{HOBr})}=0.02, \gamma_{0(\mathrm{BrONO} 2)}=0.036$ and $\gamma_{0 \text { (N2O5) }}=0.025$. The background aerosol density data are taken from measurements in the boundary layer (Heintzenberg et al., 2000), in the free troposphere and stratosphere (Schröder et al., 2002) and Reactions (R1)-(R3) are assumed to occur on background aerosols when there is no rainfall in a gridbox, otherwise, the hydrolysis reaction $\mathrm{BrONO}_{2}+\mathrm{H}_{2} \mathrm{O} \rightarrow \mathrm{HOBr}+\mathrm{HNO}_{3}$ occurs. Note that the additional sea salt aerosol from blowing snow will further enhance the recycling (R1-R3) and may cause much higher $\mathrm{BrO}$ fraction in total inorganic bromine species; this is not included in this study.

\subsection{Model experiments}

Table 1 lists the model experiments conducted. The BASE run includes the three major bromine sources from blowing snow, open ocean sea salt and bromocarbons. The OCEAN run omits the blowing snow sea salt source. The noHET run is the same as BASE but with the heterogeneous Reactions (R1)-(R3) switched off in order to isolate the effect of heterogeneous recycling on the $\mathrm{BrO}$ fraction. The noBr run contains no bromine chemistry. 

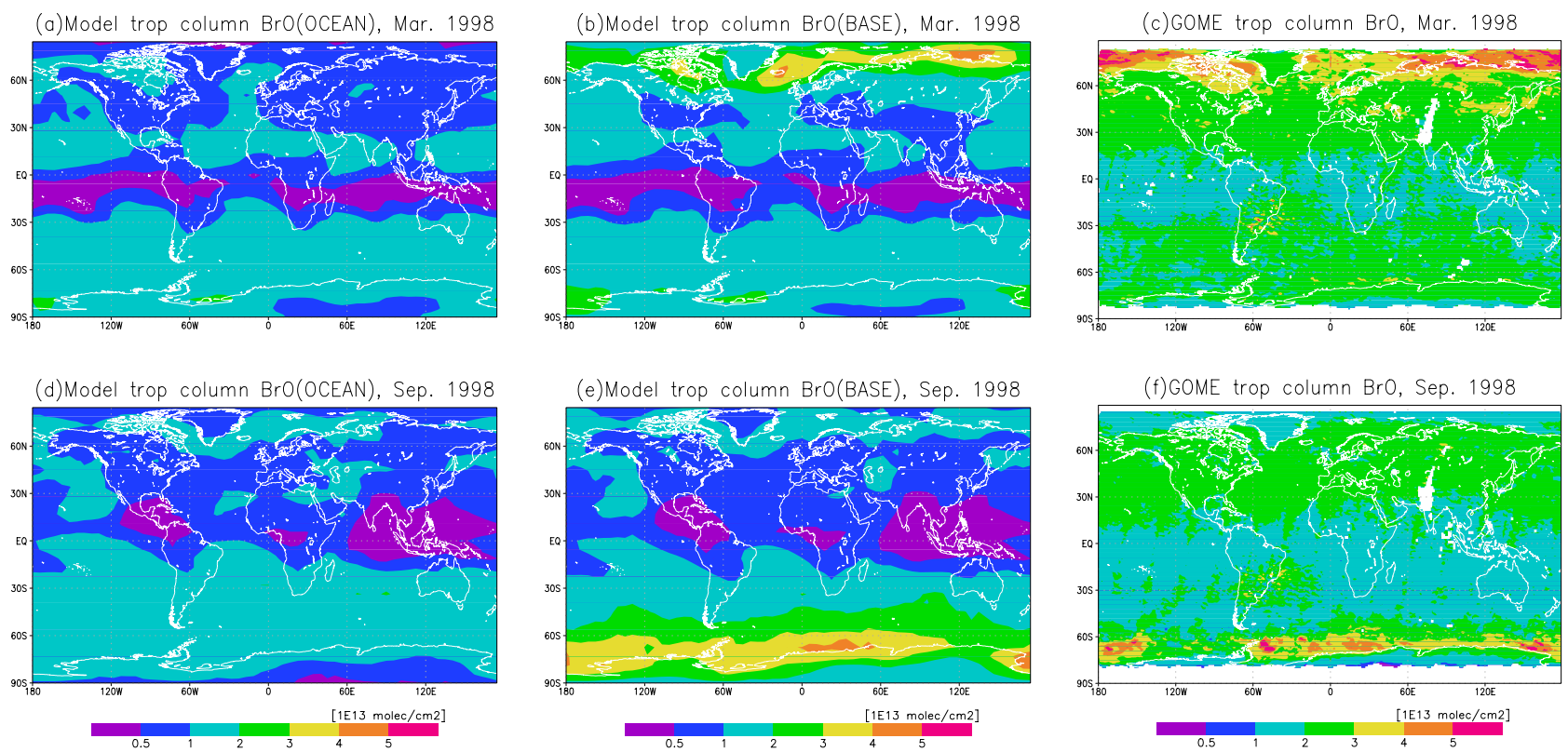

Fig. 1. Comparisons of simulated tropospheric column BrO from OCEAN run (a and $\mathbf{d})$ and BASE run (b and e) and retrieved tropospheric column $\mathrm{BrO}$ (c and f) in March and September of year 1998, respectively. Note that the model data represent BrO during daytime (local 9 a.m.-3 p.m.). The unit of column BrO is $1 \times 10^{13}$ molecules $/ \mathrm{cm}^{2}$.

Table 1. Model experiments.

\begin{tabular}{ll}
\hline Experiments & Brief descriptions \\
\hline BASE & $\begin{array}{l}\text { Includes bromine sources from blowing snow sea } \\
\text { salt, open ocean sea salt and bromocarbons }\end{array}$ \\
OCEAN & $\begin{array}{l}\text { Includes only bromine sources from } \\
\text { open ocean sea salt and bromocarbons }\end{array}$ \\
noHET & $\begin{array}{l}\text { Same as BASE run, but with heterogeneous } \\
\text { Reactions (R1)-(R3) switched off }\end{array}$ \\
noBr & $\begin{array}{l}\text { All bromine chemistry switched off } \\
\text { Same as BASE, but with doubled DF for } \\
\text { blowing-snow sea salt }\end{array}$ \\
Arctic1X & $\begin{array}{l}\text { Same as BASE, but in Arctic, the snow salinity on } \\
\text { young sea ice is set to the same as in the Antarctic }\end{array}$ \\
\hline
\end{tabular}

All experiments include a one-year model spin-up run. The second year results are used for analysis.

In addition, we have run two sensitivity experiments. The $2 \mathrm{XDF}$ run is the same as the BASE run but with doubled sea salt bromine DF just for the blowing-snow source. The Arctic1X uses the same snow salinity in the Arctic as in the Antarctic (whereas in BASE the Arctic salinity is 3.5 times larger, see Sect. 2.4).

For all experiments, the model output frequency is $2 \mathrm{~h}$ to ensure a close solar zenith angle match with the GOME data. All the experiments included a one year spin-up run.

\section{Satellite tropospheric BrO retrieval}

The Global Ozone Monitoring Experiment (GOME) (Burrows et al., 1999) is a remote-sensing instrument observing the sunlight backscattered from the earth in nadir viewing geometry. Launched in April 1995 aboard the ERS-2 platform, GOME is an ultraviolet/visible spectrometer measuring in the spectral interval from 240 to $793 \mathrm{~nm}$ with a spectral resolution of 0.2 to $0.4 \mathrm{~nm}$. The GOME pixel size is about $320 \times 40 \mathrm{~km}^{2}$ and global coverage is achieved within three days.

In the framework of the ESA TEMIS project (http://www. temis.nl), a tropospheric $\mathrm{BrO}$ column product has been developed based on GOME measurements (data is available from the authors on request). The tropospheric $\mathrm{BrO}$ columns are retrieved in three steps. First, the $\mathrm{BrO}$ absorption is determined from the measured calibrated radiances using the DOAS method in the wavelength interval from 344.7 to $359 \mathrm{~nm}$ (Van Roozendael et al., 2002). In a second step, the stratospheric component of the signal is removed by subtracting the stratospheric $\mathrm{BrO}$ column, calculated using a stratospheric $\mathrm{BrO}$ climatology. The stratospheric $\mathrm{BrO}$ correction is based on a dynamical climatology generated from the BASCOE 3D chemical transport model (Theys et al., 2009). This climatology explicitly accounts for the impact of atmospheric dynamics and photochemistry on the stratospheric $\mathrm{BrO}$ distribution. In the last step, the tropospheric residual is converted to a tropospheric vertical column by applying an air mass factor to account for the vertical sensitivity of the measurement. In this air mass factor calculation, a 


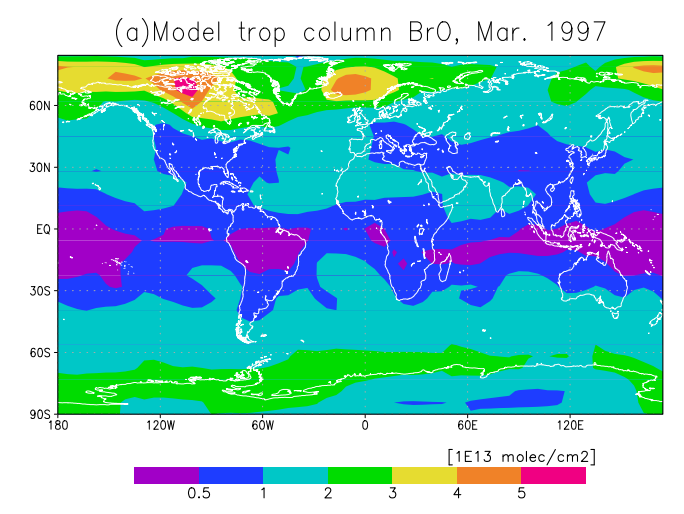

(b)GOME trop column BrO, Mar. 1997

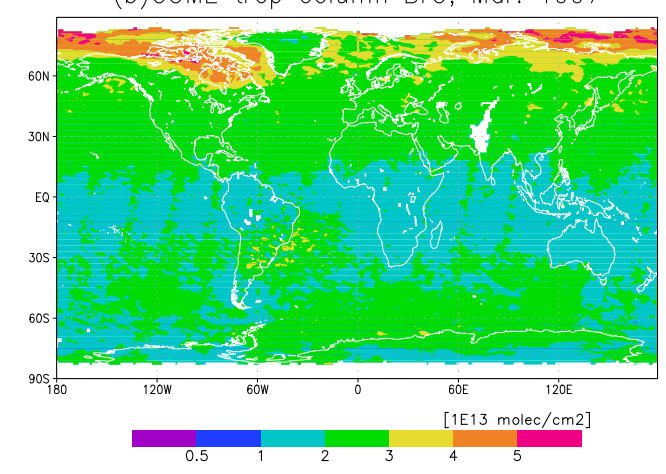

Fig. 2. Comparisons of BASE run (a) and retrieved (b) tropospheric column BrO in March of 1997.

priori information is needed on the surface albedo (Koelemeijer et al., 2003), the clouds (Koelemeijer et al., 2001) (a cloud screening removes the measurements with a cloud fraction larger than 0.4) and the shape of the vertical distribution of tropospheric $\mathrm{BrO}$. The latter profile shape is however largely unknown in the troposphere. For bright surfaces (snow-ice cover), the air mass factor is weakly dependent on the shape of the profile and a constant concentration profile in the first kilometre has been chosen. Over dark surfaces (such as oceans), the measurement sensitivity is strongly reduced in the boundary layer and we have assumed the tropospheric $\mathrm{BrO}$ profile to have only a contribution in the freetroposphere (with a bulk located at $6 \mathrm{~km}$ altitude). As a consequence, the resulting tropospheric $\mathrm{BrO}$ columns there will underestimate any $\mathrm{BrO}$ amount present in the boundary layer.

The total error on the tropospheric $\mathrm{BrO}$ columns is estimated to be about $1-2 \times 10^{13} \mathrm{molec} / \mathrm{cm}^{2}$, when all sources of uncertainties in the retrieval are taken into account.

\section{Results and analysis}

Figure 1 shows a large-scale comparison between the model tropospheric $\mathrm{BrO}$ (from both the BASE and OCEAN runs) and the tropospheric $\mathrm{BrO}$ retrieved from the GOME satellite instrument (as described in Sect. 3), for March and Septem-

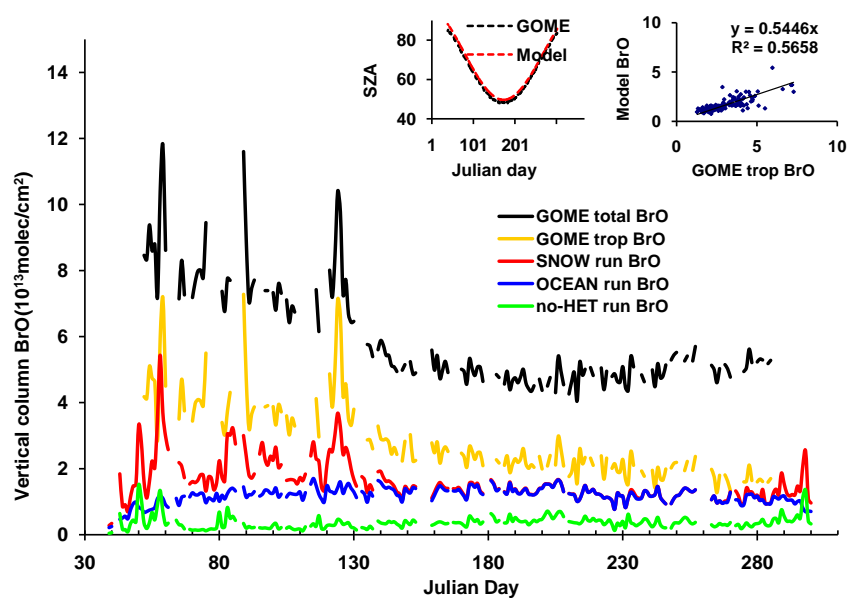

Fig. 3. Comparisons of modeled tropospheric column $\mathrm{BrO}$ (red) with GOME total vertical column BrO (black) and retrieved tropospheric BrO (yellow) over Barrow $\left(73^{\circ} \mathrm{N}, 157^{\circ} \mathrm{W}\right.$ ) for year 1998. The model experiments, the OCEAN and noHET runs, are shown in blue and green lines, respectively. The inset plot (left) shows solar zenith angle (SZA) of the model output (red) and satellite observation (black); the inset plot (right) shows the relationship and regression coefficient between retrieved and model tropospheric column $\mathrm{BrO}$ (BASE run).

ber 1998, respectively, covering boreal and austral spring time. Figure 1 shows that our model successfully captures the main features of the distribution of satellite-based tropospheric $\mathrm{BrO}$ in polar region only if the snow-sourced bromine is included. For example, the highest $\mathrm{BrO}$ in the North American sector, along the coast of the Arctic ocean, and the 'ringlike' $\mathrm{BrO}$ structure around the Antarctic are both well reproduced in the BASE run but are not seen in the OCEAN run. Simulated monthly mean daytime tropospheric column $\mathrm{BrO}$ ranges from $<0.5 \times 10^{13}$ molecules $/ \mathrm{cm}^{2}$ in the tropics, where sources are weak and removal of inorganic bromine is strong, to $>4 \times 10^{13}$ molecules $/ \mathrm{cm}^{2}$ over polar sea ice, mainly reflecting the blowing-snow source. Compared with retrieved data, modeled tropospheric $\mathrm{BrO}$ is in general lower by $\sim 1 \times 10^{13}$ molecules $/ \mathrm{cm}^{2}$, but qualitative agreement between modeled and retrieved tropospheric $\mathrm{BrO}$ is good in polar spring.

In marginal regions between sea ice and the open ocean, such as over the Southern Ocean and the North Atlantic ocean where strong surface winds are frequently observed, the simulated tropospheric $\mathrm{BrO}$ is larger than the retrieved $\mathrm{BrO}$. Although the model may overestimate ocean sea salt $/ \mathrm{Br}$ production in high latitudes under particular conditions (such as lower water temperature, affecting sea salt production (Mårtensson et al., 2003), higher ambient air relative humidity RH $(>80 \%)$, affecting particle size and lifetime (Smith et al., 1993), and lower ambient air acidity, affecting bromine release (Ayers et al., 1999)), the satellite sensor also possibly underestimates marine boundary layer $\mathrm{BrO}$ over such dark 

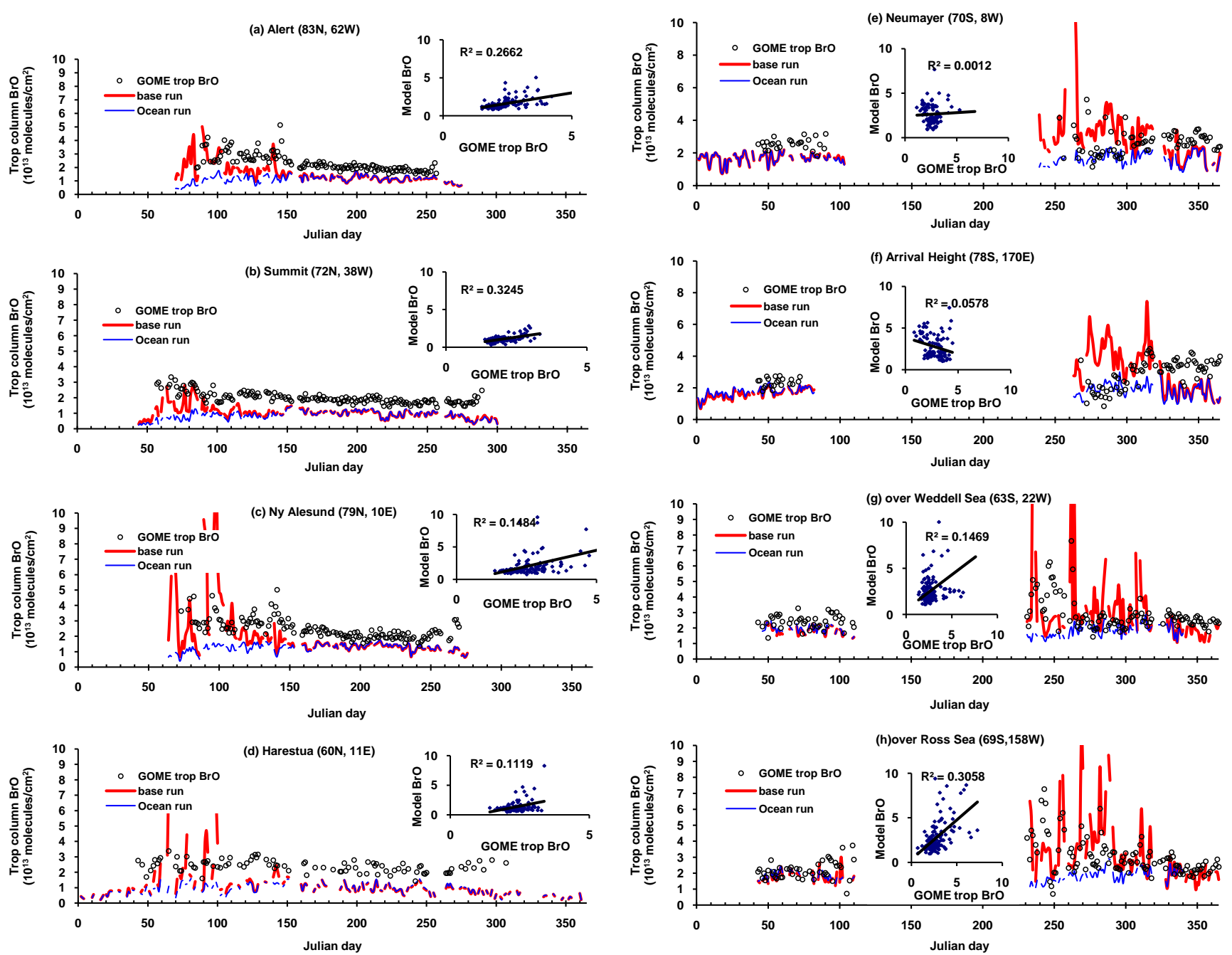

Fig. 4. Comparisons of modeled and retrieved tropospheric column BrO over 8 sites in the $\mathrm{NH}$ and $\mathrm{SH}$ polar region for year 1998. The inset plot shows the relationship and regression coefficient between the retrieved and modeled tropospheric BrO. The model results are from BASE run.

surfaces. Over high latitudes in North America, the modeled $\mathrm{BrO}$ is lower than the retrieved $\mathrm{BrO}$ in March 1998. However, we have conducted multi-year simulations which show that elevated $\mathrm{BrO}$, similar to the retrieved $\mathrm{BrO}$, can also be predicted (e.g. in 1997 as shown in Fig. 2).

There is also a discrepancy between model and observations in the tropics (see Fig. 1), where simulated tropospheric $\mathrm{BrO}$ is generally lower than the retrieved value. Lowest $\mathrm{BrO}$ is found over tropical land areas and in areas with strong precipitation, such as over Maritime Continent in September where wet deposition plays an important role in washout inorganic bromine species. Discrepancies in the tropics, of course, are not related to our modeled polar emissions but do possibly point to problems with our open ocean sea salt or halocarbon emissions. However we should also note that the tropical region is the place where the retrieval error is quite large because of the weaker signals there and large errors in the air mass factor (AMF).
Turning from regional to local scales, Fig. 3 shows a detailed comparison between model and satellite-based results (both the GOME total column and the retrieved tropospheric column) for comparable solar zenith angles (SZA) at Barrow $\left(73^{\circ} \mathrm{N}, 157^{\circ} \mathrm{W}\right)$ in 1998 . Model and retrieved tropospheric $\mathrm{BrO}$ correlate significantly $\left(r^{2}=0.57\right)$ at Barrow where frequent BEs are observed. Compared to the observed $10 \mathrm{~m}$ wind speeds at Barrow airport (data from National Climatic Data Center), model daily mean surface wind speeds (with horizontal resolution of $5.6^{\circ}$ ) are on average $1 \mathrm{~m} / \mathrm{s}$ smaller (Appendix Fig. A1). Through a detailed comparison with tropospheric column $\mathrm{BrO}$ data as shown in the Appendix Fig. A1, we find that, during most periods, strong surface winds correspond to elevated $\mathrm{BrO}$ at Barrow, but not all elevated $\mathrm{BrO}$ is accompanied by windy conditions. For example, during Julian days 5860, 89-91 and 122-127, big BEs are captured by both satellite and simulation, but surface wind speeds are very 

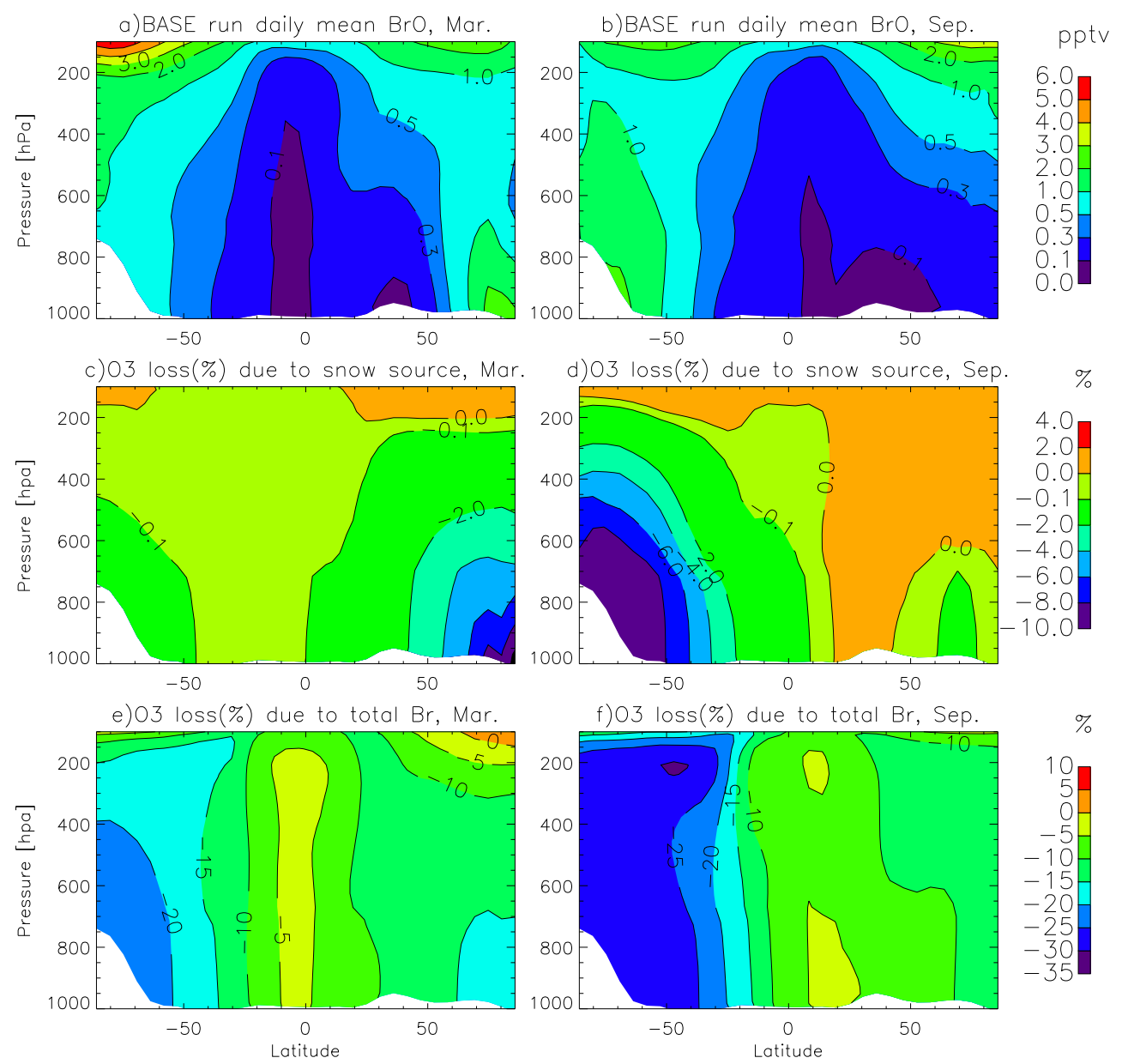

Fig. 5. Zonal mean fields of $\mathrm{BrO}$ and ozone loss due to bromine chemistry. Zonal daily averaged $\mathrm{BrO}$ (pptv) in (a) March and (b) September of 1998, from BASE run, with plotted interval of 1 pptv at $\mathrm{BrO}>1$ pptv. The calculated ozone reductions (\%) due to bromine explosion (snow source) are show in (c) and (d) (calculated according to formula: (BASE run - OCEAN run)/(BASE run) $\times 100 \%$ ) with interval of $2 \%$ at ozone loss $>-2 \%$. The ozone reductions due to all bromine sources are shown in (e) and (f) by comparing BASE run with noBr run (calculated according to formula (BASE run - noBr run)/(noBr run) $\times 100 \%$ ).

low indicating non-local sources and long-range transport of lifted bromine in the free troposphere.

Further comparisons with retrieved tropospheric $\mathrm{BrO}$ at different sites are shown in Fig. 4. Significant correlation is seen at all the Arctic sites (we define the relationship as significant, if $r^{2}>0.1$, at a probability level of $\mathrm{p}=0.01$, meaning a $99 \%$ probability of making a correct statement, with number of degrees of freedom $>100$ ). In the Southern Hemisphere, significant correlation is seen over hotspots such as the Weddell Sea (approximately $70^{\circ} \mathrm{S}, 40^{\circ} \mathrm{W}$ ) and the Ross Sea (approximately $75^{\circ} \mathrm{S}, 180^{\circ} \mathrm{W}$ ) where $\mathrm{BrO}$ are frequently elevated during spring (Fig. 4g and h). But for coastal sites Neumayer $\left(70^{\circ} \mathrm{S}, 8^{\circ} \mathrm{W}\right)$ and Arrival Heights $\left(78^{\circ} \mathrm{S}, 170^{\circ} \mathrm{E}\right)$, the correlation is poor (Fig. 4e and f). Unlike in the $\mathrm{NH}$ all multiyear sea ice has been ruled out as a sea salt source. However, the large Ross ice shelf near Arrival Heights is a sea salt and $\mathrm{Br}$ source, explaining why the model overesti- mates $\mathrm{BrO}$ at Arrival Heights during spring. The poor correlation at Neumayer could be due to the coarse model resolution. Noteworthy are several short-term BE episodes that are consistently captured by both measurement and model results. It is of course unrealistic to expect excellent correlations at all sites, given the coarse model resolution. More importantly, it is important to realize that, in all cases, the elevated $\mathrm{BrO}$ in polar spring cannot be simulated without including the blowing-snow source of bromine. Note that in polar regions, extremely high tropospheric $\mathrm{BrO}\left(>10 \times 10^{13}\right.$ molecules $/ \mathrm{cm}^{2}$ ) can be simulated during some very windy days which is somewhat unrealistic indicating that bromine release could be non-linear with fresh sea salt (alkalinity) production. For example, higher fresh sea salt supply, e.g. over the Southern Ocean, results in lower sea salt acidity or higher pH (Kerkweg et al., 2008), and thus could lower bromine release there (Breider et al., 2009). 

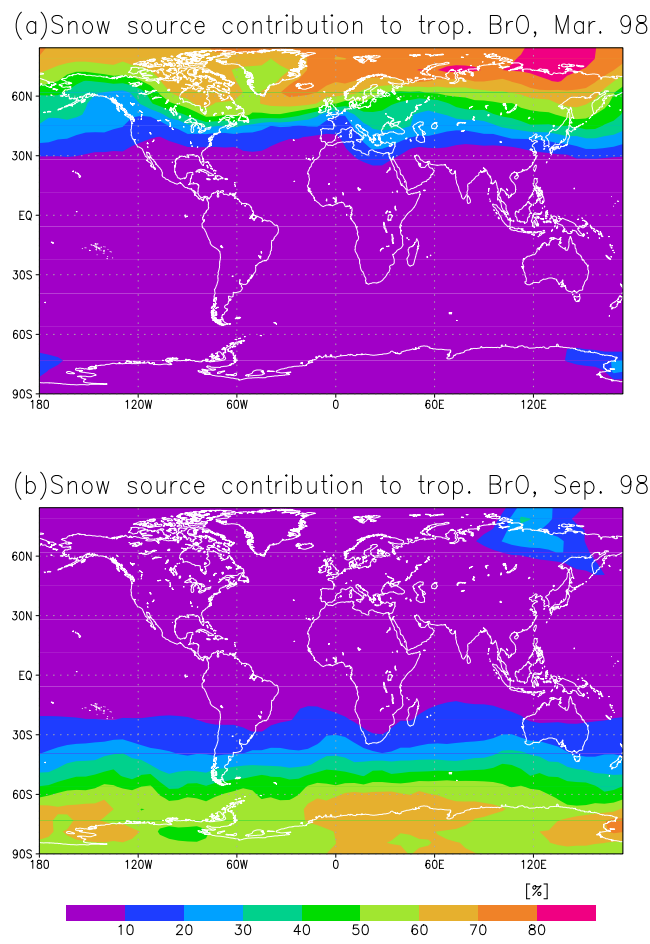

Fig. 6. Percentage contribution of blowing snow source to the simulated tropospheric column $\mathrm{BrO}$ in (a) March and (b) September of 1998. Values are calculated according to the formula: (BASE run OCEAN run $) /($ BASE run $) \times 100 \%)$.

The differences in modeled tropospheric column $\mathrm{BrO}$ between BASE run and OCEAN run as shown in Figs. 3 and 4 clearly shown the contribution to polar bromine from the blowing snow. It can be seen that the blowing-snow source leads to a significant increase in $\mathrm{BrO}$ in spring and a modest increase in autumn. The good agreement between model and observations over regions with elevated $\mathrm{BrO}$, especially in the Arctic where blowing-snow is the major source, suggests that the blowing-snow-bromine may be properly parameterized relative to the sea salt source from the open ocean. When the heterogeneous Reactions (R1)-(R3) are excluded, $\mathrm{BrO}$ is only $30 \%$ of the BASE run value indicating the important role of heterogeneous reactivation in sustaining a high fraction of radical bromine $(\mathrm{BrO}+\mathrm{Br})$ in total gas phase inorganic bromine. When heterogeneous reactions are included, the mid-day $\mathrm{BrO}$ accounts for almost $50 \%$ of total inorganic bromine in the boundary layer.

Figure $5 \mathrm{a}$ and $\mathrm{b}$ shows the zonal mean daily averaged $\mathrm{BrO}$ in March and September of 1998. In the polar boundary layer, the spring daily mean $\mathrm{BrO}$ is $1-2$ pptv, which is consistent with recent in situ measurements in the Antarctic (SaizLopez et al., 2007). In the Arctic spring, highest $\mathrm{BrO}$ is confined to the lower troposphere whereas high $\mathrm{BrO}$ is found throughout the troposphere over Antarctica (and much is of oceanic origin), reflecting dynamical process in controlling
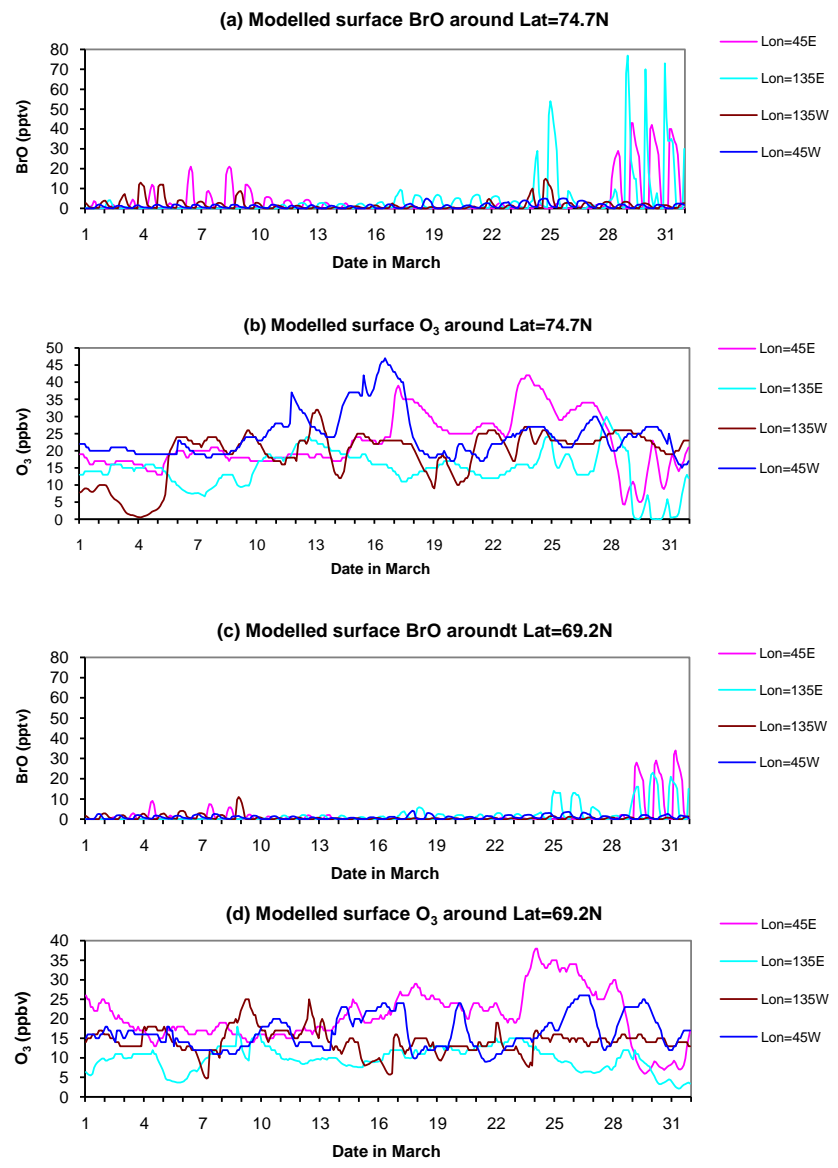

Fig. 7. BASE run surface $\mathrm{BrO}$ and ozone mixing ratios at different longitude locations along two model latitudes of $74 .^{\circ} \mathrm{N}$ (a and b) and $69.2^{\circ} \mathrm{N}$ (c and d) in March 1998.

vertical transport of BrO. During polar autumn, the daily mean value drops significantly, but in the $\mathrm{SH}$, the autumn daily $\mathrm{BrO}$ is still greater than $0.5 \mathrm{pptv}$, and is significantly larger than the Arctic level of $\sim 0.2$ pptv, reflecting the larger sea salt production rate from the Southern Ocean.

During polar spring, the snow source plays a dominant role (Fig. 6). 70-80\% of the Arctic tropospheric $\mathrm{BrO}$ is from the snow source, which is mainly due to the higher snow salinity used in the Arctic, while in the SH, this figure drops to 50$60 \%$. In autumn this source only contributes a few percent, with contributions locally larger than $10 \%$. Due to transport effects, a significant contribution from the springtime snow source can be found in mid-latitudes and over the Antarctic continent.

We have modeled complete removal of ozone locally during intense BEs; however, most of the time in our integration, mixing within the model boundary layer brings ozone to the surface maintaining concentrations of order $10 \mathrm{ppbv}$ (Fig. 7). Here, we focus on the impact on modelled zonal mean ozone. Comparing the BASE run with the OCEAN run to determine the net effect of the snow source, we see an important 

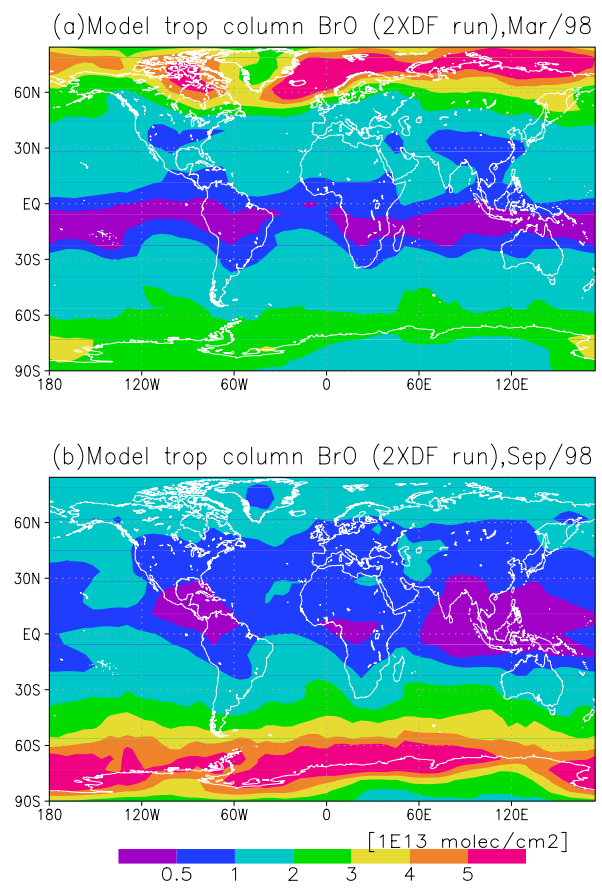

Fig. 8. Tropospheric column $\mathrm{BrO}$ in March (a) and Septerber (b) from $2 \mathrm{XDF}$ run. The unit of column BrO is $1 \times 10^{13}$ molecules $/ \mathrm{cm}^{2}$.

contribution throughout the high latitude troposphere where a monthly mean ozone difference of up to $8 \%$ is obtained (Fig. 5c and d). This ozone difference reflects ozone loss just due to blowing snow events and is in addition to ozone losses caused by bromine emitted from the open ocean sea salt and released from bromocarbons. Comparing the BASE run with the noBr run, we find that the bromine chemistry in the troposphere reduces mean tropospheric ozone amounts by $5-30 \%$ (Fig. 5e and f), which is consistent with previous estimates (von Glasow et al., 2004; Yang et al., 2005). In the upper troposphere and lower stratosphere, significant ozone reductions of $\sim 10 \%$ in the $\mathrm{NH}$ and $\sim 20 \%$ in the SH are simulated.

\section{Model sensitivities}

Figure 8 shows the tropospheric $\mathrm{BrO}$ column in the $2 \mathrm{XDF}$ run (with doubled DF for snow-Br) in March and September. Compared with the BASE run (Fig. 1), tropospheric $\mathrm{BrO}$ increases by $80-100 \%$ in the Arctic and $60-80 \%$ in the Antarctic, respectively. Obviously, the almost linear response to DF in the Arctic reflects the dominant snow-Br source due to the large sea ice coverage. Significant increases in $\mathrm{BrO}$ can also be seen in mid-latitudes attributable to long-range transport. Clearly, in the atmosphere, spatial and temporal variations in DF could have a significant impact on the observed BrO distribution. In a recent application of the model to the tropical Atlantic (O'Brien et al., 2009), the model failed to reproduce the high $\mathrm{BrO}$ (2-3 ppbv) observed there, which could be partly explained by the low DF used in the model, as

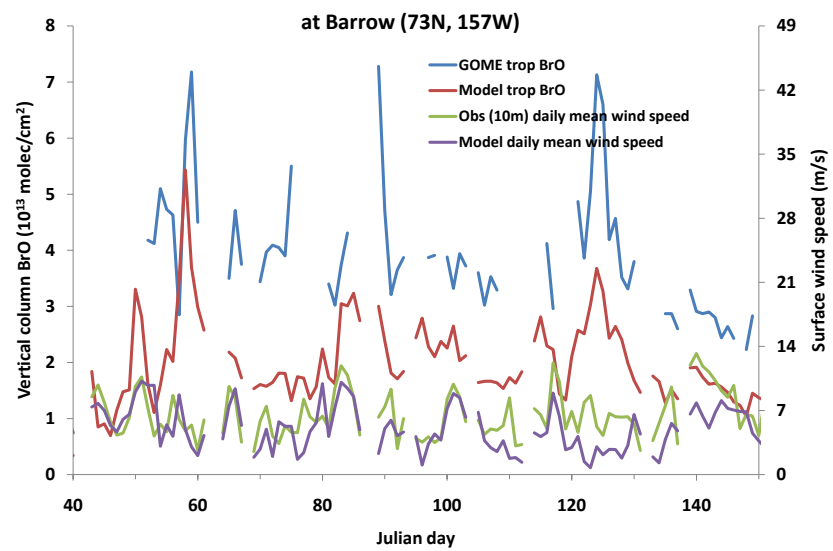

Fig. A1. Observed $10 \mathrm{~m}$ daily mean wind speeds at Barrow airport (data from National Climatic Data Center) during Julian days 40 150,1998 , and model daily mean surface wind speeds. Also shown are GOME and model tropospheric column BrO at Barrow.

recent observation indicates that the sea salt bromine near Cape Verde is heavily depleted (Müller et al., 2010). It is clearly necessary to work towards including a detailed sea salt microphysical-chemical module to study bromine chemistry at the global scale.

In the Arctic1X run, the Arctic snow salinity was reduced by a factor of 3.5. Compared with the BASE run, tropospheric $\mathrm{BrO}$ in the Arctic is reduced by up to $50 \%$, but is still significantly elevated. Compared with the OCEAN run, the snow contribution to the total column $\mathrm{BrO}$ over Arctic is still significant (40-70\%). The non-linear response to salinity can be explained (see Sect. 2.4) by the compensating increases in fine sea salt aerosols production (dry diameter $<10 \mu \mathrm{m}$ ).

\section{Conclusions}

Our simulations show that the open ocean and organic bromine source are not sufficient to explain the bromine explosions (BEs), whereas the bromine sourced from blowing snow is. BEs are consistent with bromine release in blowing snow events, when additional sea salt aerosols containing $\mathrm{Br}$ are created, leading both to the liberation of more $\mathrm{Br}^{-}$and to more rapid reactivation of gaseous $\mathrm{HBr}$ by heterogeneous reactivation. This blowing-suspension phenomenon can explain the bromine source during BEs reasonably well in both magnitude and duration. Heterogeneous reactions on the sea salt aerosol maintain the high $\mathrm{BrO}$ fraction of total inorganic bromine.

From this analysis, it is possible to predict conditions under which bromine explosion events may occur. A relatively dry and windy environmental condition favors a large sublimation rate during a blowing event. If this occurs over a region with high-saline-contaminated snow and if there is sufficient availability of acidifying trace gases to titrate the sea salt alkalinity, a bromine explosion is likely. We also find that the bromine from blowing snow can be transported long 
distances and even contribute significantly to the $\mathrm{BrO}$ at midlatitudes. Since tropospheric ozone amounts are significantly affected by this mechanism, this constitutes a potential influence of changing climatic conditions on oxidizing capacity.

Note that snow packs generally will also constitute a bromine source, but they are likely modest relative to blowing snow. Similarly, frost flowers growing on young sea ice have very high salinity, but only a small fraction can form fine sea salt with $d_{\text {dry }}<10 \mu \mathrm{m}$ after wind-crop. Actually, it is more likely that frost flowers affect bromine chemistry in an indirect pathway by contaminating the adjacent snow; the resultant salinity will be lower and could substantially favor fine sea salt production.

While we have demonstrated that blowing snow is a plausible mechanism by which bromine may be released into the atmosphere, it is clear that further work is required. In particular, our sensitivity experiments show that further information on both DF and snow salinity is required. As Earth System models are developed further, more detailed processbased treatments of the bromine release need to be developed.

Acknowledgements. This work was supported by NCAS and NERC through the AMMA-UK project. BrO product is from BIRA-IASB and has been financially supported by the ESA DUE TEMIS project and the Belgian Science Policy Office through the Prodex program. We thank R. Kwok for supplying Arctic multi-year sea ice data. We acknowledge the National Snow and Ice Data Center (NSIDC) for the data set of DMSP SSM/I Daily and Monthly Polar Gridded Sea Ice Concentrations.

Edited by: J. B. Burkholder

\section{References}

Alvarez-Aviles, L., Simpson, W. R., Douglas, T. A., Sturm, M., Perovich, D., and Domine, F.: Frost flower chemical composition during growth and its implications for aerosol production and bromine activation, J. Geophys. Res., 113, D21304, doi:10.1029/2008JD010277, 2008.

Ayers, G. P., Gillett, R. W., Cainey, J. M., and Dick, A. L.: Chloride and bromide loss from sea-salt particles in Southern Ocean air, J. Atmos. Chem., 33, 299-319, 1999.

Barrie, L. A., Bottenheim, J. W., Schnell, R. C., Crutzen, P. J., and Rasmussen, R. A.: Ozone destruction and photochemical reactions at polar in the lower Arctic atmosphere, Nature, 334, 138141, 1998.

Box, J. E., Bromwich, D. H., and Bai, L.-S.: Greenland ice sheet surface mass balance 1991-2000: Application of Polar MM5 mesoscale model and in situ data, J. Geophys. Res., 109, D16105, doi:10.1029/2003JD004451, 2004.

Breider, T., Chipperfield, M. P., Richards, N. A. D., Carslaw, K. S., Mann, G. W., and Spracklen, D. V.: The impact of BrO on dimethylsulfide in the remote marine boundary layer, Geophys. Res. Lett., 37, L02807, doi:10.1029/2009GL040868, 2009.

Burrows, J. P., Weber, M., Buchwitz, M., Rozanov, V., LadstatterWeissenmayer, A. Richter, A., De Beek, R., Hoogen, R., Bramstedt, K., Eichmann, K. W., Eisinger, M., and Perner, D.: The
Global Ozone Monitoring Experiment (GOME): mission concept and first scientific results, J. Atmos. Sci., 56, 151-175, 1999.

Comiso, J.: DMSP SSM/I daily and monthly polar gridded sea ice concentrations (1998), edited by: Maslanik, J. and Stroeve Boulder, J., Colorado, USA, National Snow and Ice Data Center, Digital media, 1990 (updated 2005).

Cook, P. A., Savage, N. H., Turquety, S., Carver, G. D., O’Connor, F. M., Heckel, A., Stewart, D., Whalley, L. K., Parker, A. E., Schlager, H., Singh, H. B., Avery, M. A., Sachse, G. W., Brune, W., Richter, A., Burrows, J. P., Purvis, R., Lewis, A. C., Reeves, C. E., Monks, P. S., Levine, J. G., and Pyle, J. A.: Forest fire plumes over the North Atlantic: p-TOMCAT model simulations with aircraft and satellite measurements from the ITOP/ICARTT campaign, J. Geophys. Res., 112, D10S43, doi:10.1029/2006JD007563, 2007.

Déry, S. J. and Yau, M. K.: A bulk blowing snow model, Bound.Lay. Meteorol., 93, 237-251, 1999.

Déry, S. J. and Yau, M. K.: Simulation of blowing snow in the Canadian Arctic using a double-moment model, Bound.-Lay. Meteorol., 99, 297-316, 2001.

Déry, S. J. and Yau, M. K.: Large-scale mass balance effects of blowing snow and surface sublimation, J. Geophys. Res., 107, 4679, doi:10.1029/2001JD001251, 2002.

Fan, S. M. and Jacob, D. J.: Surface ozone depletion in Arctic spring sustained by bromine reactions on aerosols, Nature, 359, 522524, 1992.

Foster, K. L., Plastridge, R. A., Bottenheim, J. W., Shepson, P. B., Finlayson-Pitts, B. J., and Spicer, C. W.: The role of $\mathrm{Br}_{2}$ and $\mathrm{BrCl}$ in surface ozone destruction at polar sunrise, Science, 291, 471-474, doi:10.1126/science.291.5503.471, 2001.

Hall, J. S. and Wolff, E. W.: Causes of seasonal and daily variations in aerosol sea-salt concentrations at a coastal Antarctic station, Atmos. Environ., 32, 3669-3677, 1998.

Heintzenberg, J., Covert, D. S., and Van Dingenen, R.: Size distribution and chemical composition of marine aerosols: a compilation and review, Tellus, 52B, 1104-1122, 2000.

Holmes, C. D., Jacob, D. J., and Yang, X.: Global lifetime of elemental mercury against oxidation by atomic bromine in the free troposphere, Geophys. Res. Lett., 33, L20808, doi:10.1029/2006GL027176, 2006.

Huffman, G. J., Adler, R. F., Morrissey, M. M., Curtis, S., Joyce, R., McGavock, B., and Susskind, J.: Global precipitation at onedegree daily resolution from multi-satellite observations, J. Hydrometeor., 2, 36-50, 2001.

Koelemeijer, R. B. A., Stammes, P. Hovenier, J. W., and de Haan, J. F.: A fast method for retrieval of cloud parameters using oxygen A band measurements from the Global Ozone Monitoring Experiment, J. Geophys. Res., 106(D4), 3475-3490, 2001.

Koelemeijer, R. B. A., de Haan, J. F., and Stammes, P.: A database of spectral surface reflectivity in the range $335-772 \mathrm{~nm}$ derived from 5.5 years of GOME observations, J. Geophys. Res., 108(D2), 4070, doi:10.1029/2002JD002429, 2003.

Kwok, R.: Annual cycles of multiyear sea ice coverage of the Arctic Ocean: 1999-2003, J. Geophys. Res., 109, C11004, doi:10.1029/2003JC002238, 2004.

Jones, A. E., Anderson, P. S., Begoin, M., Brough, N., Hutterli, M. A., Marshall, G. J., Richter, A., Roscoe, H. K., and Wolff, E. W.: BrO, blizzards, and drivers of polar tropospheric ozone depletion events, Atmos. Chem. Phys., 9, 4639-4652, doi:10.5194/acp-9- 
4639-2009, 2009.

Mårtensson, E. M., Nilsson, E. D., de Leeuw, G. Cohen, L. H., and Hansson, H.-C.: Laboratory simulations and parameterization of the primary marine aerosol production, J. Geophys. Res., 108(D9), 4297, doi:10.1029/2002JD002263, 2003.

Massom, R. A., Eicken, H., Haas, C., Jeffries, M. O., Drinkwater, M. R., Sturm, M., Worby, A. P., Wu, X., Lytle, V. I., Ushio, S., Morris, K., Reid, P. A., Warren, S., and Allison, I.: Snow on Antarctic sea ice, Rev. Geophys., 39, 413-445, 2001.

McConnell, J., Henderson, G., Barrie, L., Bottenheim, J., Niki, H., Templeton, E.: Photochemical bromine production implicated in Arctic boundary-layer ozone depletion, Nature, 355, 150-152, 1992.

Müller, K., Lehmann, S., van Pinxteren, D., Gnauk, T., Niedermeier, N., Wiedensohler, A., and Herrmann, H.: Particle characterization at the Cape Verde atmospheric observatory during the 2007 RHaMBLe intensive, Atmos. Chem. Phys., 10, 2709-2721, doi:10.5194/acp-10-2709-2010, 2010

O’Brien, L. M., Harris, N. R. P., Robinson, A. D., Gostlow, B., Warwick, N., Yang, X., and Pyle, J. A.: Bromocarbons in the tropical marine boundary layer at the Cape Verde Observatory - measurements and modelling, Atmos. Chem. Phys., 9, 90839099, doi:10.5194/acp-9-9083-2009, 2009.

O’Connor, F. M., Carver, G. D., Savage, N. H., Pyle, J. A., Methven, J., Arnold, S. R., Dewey, K., and Kent, J.: Comparison and visualisation of high-resolution transport modeling with aircraft measurements, Atmos. Sci. Lett., 6, 164-170, doi:10.1002/asl.111, 2005.

Rankin, A. M., Wolff, E. W., and Martin, S.: Frost flowers: implications for tropospheric chemistry and ice core interpretation, J. Geophys. Res., 107, 4683, doi:10.1029/2002JD002492, 2002.

Salawitch, R. J., Weisenstein, D. K., Kovalenko, L. J., Sioris, C. E., Wennberg, P. O., Chance, K., Ko, M. K. W., and McLinden, C. A.: Sensitivity of ozone to bromine in the lower stratosphere, Geophys. Res. Lett., 32, L05811, doi:10.1029/2004GL021504, 2005.

Saiz-Lopez, A., Mahajan, A. S., Salmon, R. A., Bauguitte, S. J.-B, Jones, A. E., Roscoe, H. K., and Plane, J. M. C.: Boundary Layer Halogens in Coastal Antarctica, Science, 317, 348-351, 2007.

Sander, R., Keene, W. C., Pszenny, A. A. P., Arimoto, R., Ayers, G. P., Baboukas, E., Cainey, J. M., Crutzen, P. J., Duce, R. A., Hönninger, G., Huebert, B. J., Maenhaut, W., Mihalopoulos, N., Turekian, V. C., and Van Dingenen, R.: Inorganic bromine in the marine boundary layer: a critical review, Atmos. Chem. Phys., 3, 1301-1336, doi:10.5194/acp-3-1301-2003, 2003.

Sander, R., Burrows, J., and Kaleschke, L.: Carbonate precipitation in brine - a potential trigger for tropospheric ozone depletion events, Atmos. Chem. Phys., 6, 4653-4658, doi:10.5194/acp-64653-2006, 2006.

Savage, N. H., Law, K. S., Pyle, J. A., Richter, A., Nüß, H., and Burrows, J. P.: Using GOME $\mathrm{NO}_{2}$ satellite data to examine regional differences in TOMCAT model performance, Atmos. Chem. Phys., 4, 1895-1912, doi:10.5194/acp-4-1895-2004, 2004.

Schmidt R. A.: Vertical profiles of wind speed, snow concentration, and humidity in blowing snow, Bound.-Lay. Meteorol., 23, 223246, 1982.

Schröder, F., Kärcher, B., Fiebig, M., and Petzold, A.: Aerosol states in the free troposphere at northern midlatitudes, J. Geo- phys. Res., 107, 8126, doi:10.1029/2000JD000194, 2002.

Seigneur, C. and Lohman, K.: Effect of bromine chemistry on the atmospheric mercury cycle, J. Geophys. Res., 113, D23309, doi:10.1029/2008JD010262, 2008.

Simpson, W. R., Alvarez-Aviles, L., Douglas, T. A., Sturm, M., and Domine, F.: Halogens in the coastal snow pack near Barrow, Alaska: evidence for active bromine air-snow chemistry during springtime, Geophys. Res. Lett., 32, L04811, doi:10.1029/2004GL021748, 2005.

Simpson, W. R., Carlson, D., Hnninger, G., Douglas, T. A., Sturm, M., Perovich, D., and Platt, U.: First-year sea-ice contact predicts bromine monoxide $(\mathrm{BrO})$ levels at Barrow, Alaska better than potential frost flower contact, Atmos. Chem. Phys., 7, 621-627, doi:10.5194/acp-7-621-2007, 2007.

Smith, M. H., Park, P. M., and Consterdine, I. E.: Marine aerosol concentrations and estimated fluxes over the sea, Q. J. Roy. Meteor. Soc., 119, 809-824, 1993.

Theys, N., Van Roozendael, M., Errera, Q., Hendrick, F., Daerden, F., Chabrillat, S., Dorf, M., Pfeilsticker, K., Rozanov, A., Lotz, W., Burrows, J. P., Lambert, J.-C., Goutail, F., Roscoe, H. K., and De Mazière, M.: A global stratospheric bromine monoxide climatology based on the BASCOE chemical transport model, Atmos. Chem. Phys., 9, 831-848, doi:10.5194/acp-9-831-2009, 2009.

Van Roozendael, M., Wagner, T., Richter, et al.: Intercomparison of $\mathrm{BrO}$ measurements from ERS-2 GOME, ground-based and balloon platforms, Adv. Space Res., 29, 1661-1666, 2002.

Voulgarakis, A., Yang, X., and Pyle, J. A.: How different would tropospheric oxidation be over an ice-free Arctic?, Geophys. Res. Lett., 36, L23807, doi:10.1029/2009GL040541, 2009.

von Glasow, R., von Kuhlmann, R., Lawrence, M. G., Platt, U., and Crutzen, P. J.: Impact of reactive bromine chemistry in the troposphere, Atmos. Chem. Phys., 4, 2481-2497, doi:10.5194/acp4-2481-2004, 2004.

von Glasow, R. and Crutzen, P. J.: Model study of multiphase DMS oxidation with a focus on halogens, Atmos. Chem. Phys., 4, 589608, doi:10.5194/acp-4-589-2004, 2004.

Wang, K. Y., Pyle, J. A., Sandersen, M. G., and Bridgeman, C.: Implimentation of a convective atmospheric boundary layer scheme in a tropospheric chemistry transport model, J. Geophys. Res., 104, 23729-23745, 1999.

Warwick, N. J., Pyle, J. A., Carver, G. D., Yang, X., Savage, N. H., O'Connor, F. M., and R. A. Cox, R. A.: Global modeling of biogenic bromocarbons, J. Geophys. Res., 111, D24305, doi:10.1029/2006JD007264, 2006.

Wessel, S., Aoki, S., Winkler, P., Weller, R., Herber, A., Gernandt, H., and Schrems, O.: Tropospheric ozone depletion events in polar regions: a comparison of observations in the Arctic and Antarctic, Tellus, 50B, 34-50, 1998

World Meteorological Organization (WMO): Global ozone research and monitoring project, in: Scientific Assessment of Ozone Depletion: 2002, Rep. 47, Geneva, 2003.

Yang, X., Cox, R. A., Warwick, N. J., Pyle, J. A., Carver, G. D., O'Connor, F. M., and Savage, N. H.: Tropospheric bromine chemistry and its impacts on ozone: a model study, J. Geophys. Res., 110, D23311, doi:10.1029/2005JD006244, 2005.

Yang, X, Pyle, J. A., and Cox, R. A.: Sea salt aerosol production and bromine release: role of snow on sea ice, Geophys. Res. Lett., 35, L16815, doi:10.1029/2008GL034536, 2008. 